\title{
Implications of the xyIQ gene of TOL plasmid pWW102 for the evolution of aromatic catabolic pathways
}

\author{
Sirinun Aemprapa† and Peter A. Williams
}

Author for correspondence: Peter A. Williams. Tel: +44 1248 382362. Fax: +44 1248370731. e-mail : P.A.Williams@bangor.ac.uk

School of Biological Sciences, University of Wales, Bangor, Gwynedd LL57 2UW, UK
Pseudomonas putida strain $\mathrm{O}_{2} \mathrm{C}_{2}$ is able to grow on toluene, $m$-xylene and $p$ xylene through benzoate and the corresponding methylbenzoates (toluates). The catabolic genes are encoded on a large TOL plasmid, pWW102, of >220 kb. The complete catabolic genes were cloned on four large overlapping restriction fragments covering a total of $28 \mathrm{~kb}$ of the plasmid, which was carefully mapped by restriction enzyme analysis. The presence of the $x y /$ genes on the cloned DNA was confirmed by assay of representative enzymes of both operons. Virtually all the genes were located on the cloned DNA by hybridization of Southern blots with gene-specific probes from related pathways of other catabolic plasmids. Within the limitations of available restriction sites, the analysis showed that the genes are in two blocks. The major block carries the meta pathway operon XYIXYZLTEGFJQKIH with the two regulatory genes $x y I S R$ immediately downstream. The upper pathway operon xylUWCMAB $(M)$ is about $2-3 \mathrm{~kb}$ downstream of the regulatory genes and transcribed in the same direction as the meta pathway operon. Within each operon the gene order appears to be identical to that found in other TOL plasmids, but the relative location of the operons most closely resembles that found on plasmid pWW53, although there is no evidence of any xyI duplications on pWW102. The nucleotide sequence of the xylQ gene for the acetaldehyde dehydrogenase (acylating; ADA), together with the $3^{\prime}$-end of the upstream xylJ (for 2-oxopent-4-enoate hydratase) and the 5'-end of the downstream xyIK (for 4-hydroxy-2-oxovalerate aldolase), was determined. The xylQ gene was ligated into expression vector PTrc99a and high levels of XylQ protein were detected by enzyme assay and by SDS-PAGE. All three genes xylJQK showed a high degree of homology with genes encoding isofunctional proteins from other Pseudomonas meta pathways, the highest being with the naphthalene catabolic genes nahLOM from the plasmid of Pseudomonas sp. NCIB 9816. The implications of the sequence homologies to the evolution of these pathways are discussed.

Keywords: TOL plasmid, Pseudomonas putida, toluene/xylene catabolism, acetaldehyde dehydrogenase (acylating), $x y l Q$

\section{INTRODUCTION}

The pathway (Fig. 1) for catabolism of toluene and some substituted toluenes, such as $m$ - and $p$-xylenes, in Pseudomonas appears to be almost always plasmid- determined (Williams \& Worsey, 1976) and shares many features with the catabolic pathways of other aromatic compounds (Assinder \& Williams, 1990; Harayama \& Rekik, 1993). The genes encoding the catabolic pathway on the archetype of these TOL plasmids, pWW0, have

†Present address: Lampang Agricultural Research and Training Centre, Rajamangala Institute of Technology, PO Box 89 Maung، Lampang 52000, Thailand. Abbreviation: ADA, acetaldehyde dehydrogenase (acylating).

The GenBank accession number for the sequences reported in this paper is AF043925. 


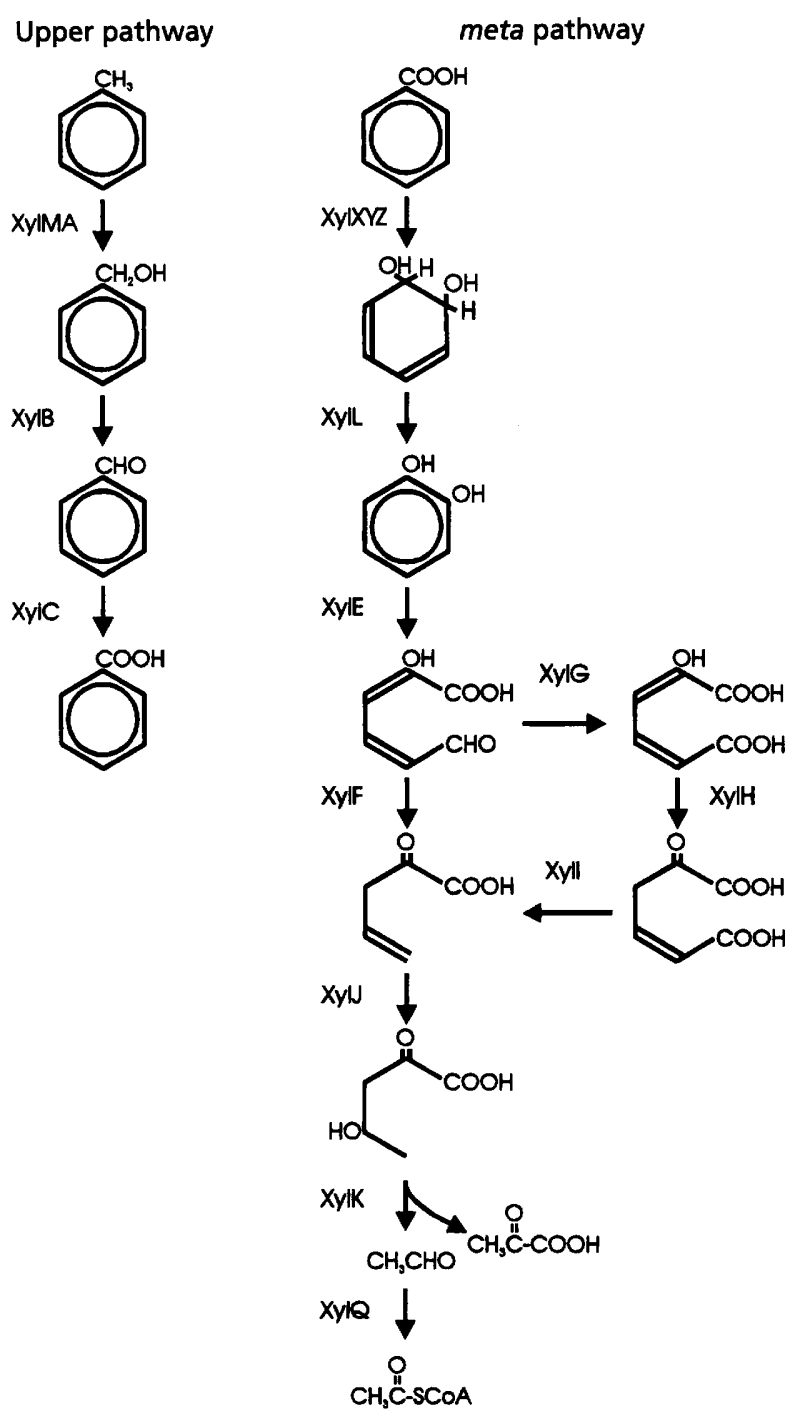

Fig. 1. $x y l$ catabolic pathway encoded by TOL plasmids. The enzymes catalysing each of the transformations are denoted by their gene-associated nomenclature. $x y l$ genes not encoding known metabolic reactions are $x y l U, W, N, T, R, S$. The function of XylT is proposed as being involved in reactivating oxidized catechol 2,3-dioxygenase (XyIE) (Polissi \& Harayama, 1993). XyIR and XylS are positive regulatory proteins. The functions of XylU, XylW and XylN are not known.

been studied in great detail (see Assinder \& Williams, 1990 ) and a number of other TOL plasmids have been investigated to a lesser extent (Pickup \& Williams, 1982; Keil \& Williams, 1985; Keil et al., 1985; Osborne et al., 1988). They all share a common organization into two operons: an 'upper pathway' operon, $x y l U W C M A B N$ (Harayama et al., 1989; Williams et al., 1997), encoding the sequential oxidation of the methyl substituent to a carboxylic acid (e.g. toluene to benzoate), and a 'meta pathway' operon, $x y l X Y Z L T E G F Q K I J H$ (Harayama \& Rekik, 1990), encoding the conversion of the carboxylic acids to central metabolites. Whereas the gene order within each of the operons appears to be con- served, the relative orientations of the two operons and the distances between them differ from plasmid to plasmid, and most carry duplications of structural and/or regulatory genes (Chatfield \& Williams, 1986; Osborne et al., 1988; O’Donnell \& Williams, 1991).

Pseudomonas putida $\mathrm{O}_{2} \mathrm{C}_{2}$ is a bacterium isolated from soil from the Netherlands which is able to grow on toluene and methyl-substituted toluenes and which contains a large TOL plasmid, pWW102. This paper reports the cloning of the $x y l$ catabolic genes from pWW102. The nucleotide sequence of $x y l Q$, for acetaldehyde dehydrogenase (acylating; ADA), is presented and the implications of comparison with genes for other ADA proteins to the evolution of aromatic pathways is considered.

\section{METHODS}

Maintenance of bacterial strains and plasmids. The strains and plasmids used in this work are listed in Table 1. Strains were routinely maintained on nutrient agar or on sensitivity test agar (Lab M) supplemented with appropriate antibiotics: kanamycin at $15 \mu \mathrm{g} \mathrm{ml}^{-1}$ and ampicillin at $100 \mu \mathrm{g} \mathrm{ml}^{-1}$.

Enzyme assays. Cell-free extracts, other than for ADA, were prepared according to Cane \& Williams (1982). The assays for catechol 2,3-dioxygenase (XylE) and for 2-hydroxymuconicsemialdehyde dehydrogenase (XylG) were carried out as described by Sala-Trepat \& Evans (1971) and for 2-hydroxymuconic-semialdehyde hydrolase (XylF) according to Duggleby \& Williams (1986). For the ADA (XylQ) assay, Escherichia coli containing recombinant plasmids bearing $x y l Q$ was inoculated at $37^{\circ} \mathrm{C}$ for $5 \mathrm{~h}$ in LB, when IPTG was added for induction of the $\mathrm{lacl}^{\mathrm{a}}$-regulated tac promoter of $\mathrm{p} \operatorname{Trc} 99 \mathrm{a}$ vector, and the cultures were incubated overnight at $30^{\circ} \mathrm{C}$ in the presence of IPTG. Extracts were prepared and assayed for ADA activity by the method of Shingler et al. (1992).

Protein electrophoresis. Cell-free extracts containing ADA were prepared as described above. SDS-PAGE was carried out by standard procedures in a PROTEANII cell (Bio-Rad).

DNA extraction and manipulation. Shotgun cloning was performed using DNA of plasmid pWW102 which was prepared by the sucrose gradient method of Wheatcroft \& Williams (1981). The vector chosen for cloning was pUC18. Restriction endonuclease digestions and DNA ligations with T4 ligase were performed by standard procedures (Sambrook et al., 1989) and recombinant transformants were selected on media containing antibiotics appropriate to the vector. Plasmid DNA was prepared for rapid screening by the method of Holmes \& Quigley (1981) and purified by $\mathrm{CsCl}$ centrifugation (Guerry et al., 1973) or using Qiagen kits. Colonies carrying recombinant plasmids expressing catechol 2,3-dioxygenase activity were detected as a result of their yellow colour after spraying with $10 \mathrm{mM}$ catechol (Worsey et al., 1978), whilst other recombinant plasmids were detected by loss of $\beta$-galactosidase activity or by colony hybridizations with probes constructed from homologous genes from other bacteria and pathways.

DNA-DNA hybridization. Restriction fragments were separated by agarose gel electrophoresis and transferred by Southern blotting (Southern, 1975) to Biodyne filter membranes. 
Table 1. Strains and plasmids used in this study

\begin{tabular}{|c|c|c|}
\hline Strain/plasmid & Relevant details & Source \\
\hline \multicolumn{3}{|l|}{ Strains } \\
\hline P. putida $\mathrm{O}_{2} \mathrm{C}_{2}$ & Wild-type $\mathrm{Mtol}^{+} \mathrm{Mxy}^{+}$ & This study \\
\hline E. coli NM522 & & Vieira \& Messing (1982) \\
\hline E. coli JM109 & & Yanisch-Perron et al. (1985) \\
\hline \multicolumn{3}{|l|}{ Plasmids } \\
\hline pTrc99a & Expression vector & Pharmacia \\
\hline pUC18 & Cloning vector & Vieira \& Messing (1982) \\
\hline pWW102 & Wild-type plasmid from strain $\mathrm{O}_{2} \mathrm{C}_{2}$ & This study \\
\hline \multicolumn{3}{|l|}{$\begin{array}{l}\text { Recombinant } \\
\text { plasmids }\end{array}$} \\
\hline pWW102-3 & $17 \mathrm{~kb}$ HindIII fragment of pWW102 in pUC18 & This study \\
\hline pWW102-6 & $11.6 \mathrm{~kb} \mathrm{BamHI}$ fragment of $\mathrm{pWW} 102$ in pUC18 & This study \\
\hline pWW102-7 & $8.6 \mathrm{~kb}$ HindIII fragment of pWW102 in pUC18 & This study \\
\hline pWW102-8 & $8.6 \mathrm{~kb}$ HindIII fragment of $\mathrm{pWW} 102$ in pUC18 (reverse orientation) & This study \\
\hline pWW102-9 & $8 \cdot 2 \mathrm{~kb}$ EcoRI fragment of $\mathrm{pWW} 102$ in pUC18 & This study \\
\hline pWW102-10 & $8 \cdot 2 \mathrm{~kb}$ EcoRI fragment of $\mathrm{pWW} 102$ in pUC18 (reverse orientation) & This study \\
\hline $\mathrm{pWW} 102-61$ & $\begin{array}{l}4 \cdot 0 \mathrm{~kb} \mathrm{BamHI}-\text { SacI fragment of pWW102-6 in pUC18 (coordinates } \\
6 \cdot 2-10 \cdot 2 \mathrm{~kb} \text { ) }\end{array}$ & This study \\
\hline pWW102-62 & $\begin{array}{l}3 \cdot 1 \mathrm{~kb} \text { SacI-SmaI fragment of pWW102-6 in pUC18 (coordinates } \\
10 \cdot 3-13 \cdot 4 \mathrm{~kb} \text { ) }\end{array}$ & This study \\
\hline pWW102-62E & $3 \cdot 1 \mathrm{~kb} S a c \mathrm{I}-\mathrm{Smal}$ fragment of pWW102-6 in pTrc99a & This study \\
\hline pWW102-622 & $\begin{array}{l}2 \cdot 2 \mathrm{~kb} \mathrm{KpnI-SmaI} \mathrm{fragment} \mathrm{of} \mathrm{pWW102-62} \mathrm{in} \mathrm{pUC18} \mathrm{(coordinates} \\
10 \cdot 8-13 \cdot 0 \mathrm{~kb} \text { ) }\end{array}$ & This study \\
\hline pWW102-623 & $\begin{array}{l}2 \cdot 1 \mathrm{~kb} \text { EcoRI-SmaI fragment of } \mathrm{pWW} 102-62 \text { in pUC18 (coordinates } \\
10 \cdot 9-13.0 \mathrm{~kb} \text { ) }\end{array}$ & This study \\
\hline pWW102-624 & $1.0 \mathrm{~kb}$ Sall fragment of pWW102-62 in pUC18 (coordinates $11 \cdot 1-12 \cdot 1 \mathrm{~kb}$ ) & This study \\
\hline pWW102-63 & $3.6 \mathrm{~kb}$ SmaI fragment of pWW102-6 in pUC18 (coordinates $13.2-16.7 \mathrm{~kb}$ ) & This study \\
\hline pVI300 & $0.87 \mathrm{~kb}$ Bal31-PstI fragment of pVI150 in pMMB66HE & Shingler et al. (1992) \\
\hline pVI308 & $1.02 \mathrm{~kb} \mathrm{HpaI-SacI}$ fragment of pVI150 in pMMB66HE & Shingler et al. (1992 \\
\hline pVI309 & $1.02 \mathrm{~kb}$ DdeI-EcoRI fragment of pVI150 in pMMB66HE & Shingler et al. (1992) \\
\hline pVI310 & $1 \cdot 13 \mathrm{~kb}$ SalI-Sall fragment of pVI150 in pMMB66HE & Shingler et al. (1992) \\
\hline pVI312 & $1.14 \mathrm{~kb}$ SauI-BstEII fragment of pVI150 in pMMB66HE & Shingler et al. (1992) \\
\hline pVI313 & $1.08 \mathrm{~kb}$ NotI-Xhol fragment of pVI150 in pMMB66HE & Shingler et al. (1992) \\
\hline pVI314 & $0.82 \mathrm{~kb} S c a \mathrm{I}-P v u \mathrm{II}$ fragment of pVI150 in pMMB66HE & Shingler et al. (1992) \\
\hline pMT100 & $1.7 \mathrm{~kb} \mathrm{BamHI}$ fragment of pWW0 in pBR322 & $\begin{array}{l}\text { J.-L.Ramos, CSIC, } \\
\text { Granada, Spain }\end{array}$ \\
\hline pWW0-7000 & $3.9 \mathrm{~kb}$ KpnI-BamHI fragment of pWW0 & Williams et al. (1997) \\
\hline pVI1:00 & $2.4 \mathrm{~kb}$ EcoRV-EcoRV fragment in pBluescript & Bartilson \& Shingler (1989) \\
\hline pWW $110-4010$ & $2 \cdot 2 \mathrm{~kb} X h o \mathrm{I}-\mathrm{X} h \mathrm{I}$ fragment of $\mathrm{pWW} 110$ in pUC18 & Carrington et al. (1994) \\
\hline pWW110-6003 & $2.7 \mathrm{~kb} E c o \mathrm{RI}-E c o \mathrm{RI}$ fragment of $\mathrm{pWW} 110$ in pUC18 & Carrington et al. (1994) \\
\hline pWW53-3301 & $17 \cdot 5 \mathrm{~kb}$ HindIII fragment of pWW53 in pKT230 & Keil et al. (1985) \\
\hline
\end{tabular}

Cloned fragments to be used as DNA probes were extracted according to the method of Girvitz et al. (1980) and labelling and detection were carried out by the ECL method (Amersham International).

Nucleotide sequence determinations. Sequences of DNA inserts in pUC18 were determined with a Pharmacia DNA Sequencing kit using the appropriate synthetic oligonucleotide primers. The complete sequences of both strands of the $x y l Q$ region were determined from the sequences of 15 individual fragments. Custom-synthesized oligonucleotide primers were used to determine the sequences across the junctions of subfragments from this region. Some sequencing reactions were performed by Alta Biosciences (University of Birmingham) using an $\mathrm{ABI}$ automatic sequencer (Applied Biosystems).
Analysis of DNA and protein sequences. Databases were searched for homologous gene sequences using the BLAST programs (Altschul et al., 1990). Manipulation and analysis of the nucleic acid sequences were done with the DNASTAR (Madison, WI, USA) nucleic acid analysis software package.

\section{RESULTS}

\section{Strain $\mathrm{O}_{2} \mathrm{C}_{2}$ and plasmid pWW102}

Strain $\mathrm{O}_{2} \mathrm{C}_{2}$ was isolated from an oil-contaminated soil in the Netherlands by W. A. Duetz (Institut für Biotechnologie, ETH Hönggerberg, Zürich, Switzerland) by directly plating supernatants from washed soil onto 


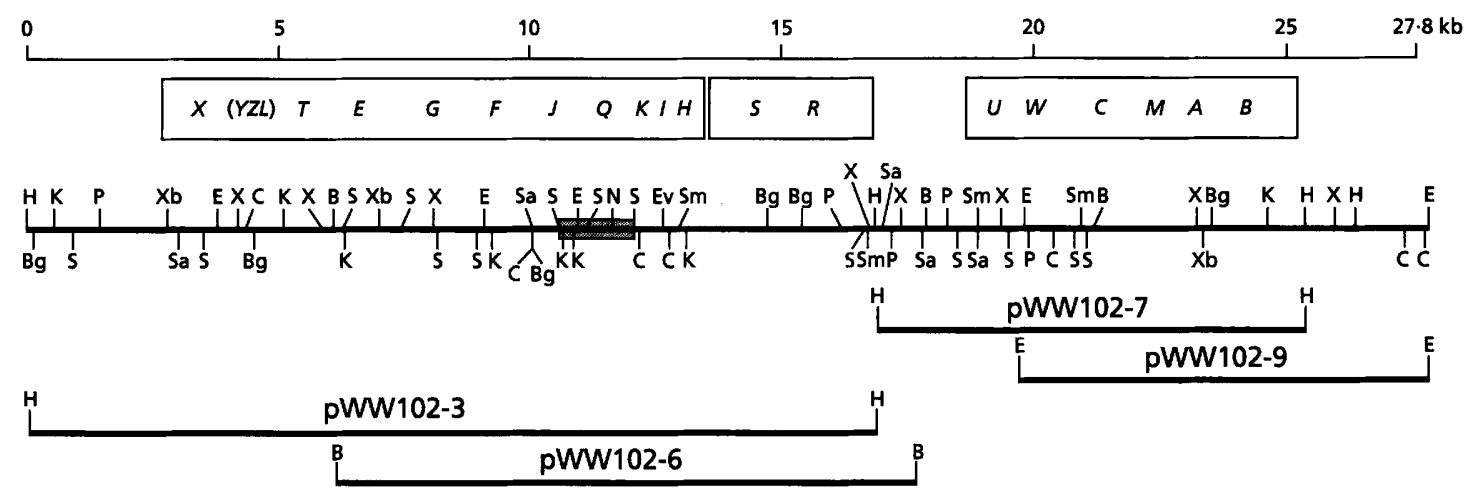

Fig. 2. Restriction map of the complete $x y /$ catabolic genes of pWW102. The inserts of the major fragments cloned into recombinant plasmids are denoted below the restriction map. The approximate position of the xyl genes is shown above the map: the range of the possible positions of each gene as determined from Southern hybridizations is presented in Table 2. The region sequenced is marked by the grey box. B, BamHI; Bg, BgIll; C, Clal; E, EcoRl; Ev, EcoRV; H, HindIII; K, Kpnl; N, Nrul; P, Pstl; S, Sall; Sa, Sacl; Sm, Smal; X, Xhol; Xb, Xbal.

minimal agar plates with toluene vapour as the sole carbon source. It has been classified by the National Culture of Industrial and Marine Bacteria as a Pseudomonas putida and it produces a blue-white fluorescence on King's medium B (King et al., 1954). It grows on toluene, $m$-xylene, $p$-xylene, benzoate, $m$-toluate (3methylbenzoate) and $p$-toluate (4-methylbenzoate): spraying colonies grown on any of these substrates with catechol produced the yellow colour characteristic of the presence of induced catechol 2,3-dioxygenase. It therefore has the phenotype characteristic of TOLplasmid-containing strains (Worsey \& Williams, 1975; Williams \& Worsey, 1976). A large plasmid, pWW102, can be isolated from cultures and measurement and summation of the sizes of fragments of the plasmid digested with a range of restriction enzymes indicate it is between 220 and $270 \mathrm{~kb}$. Growth through one cycle of benzoate in liquid culture for about 20 generations, which took 5-6 d, produced loss of the characteristic TOL phenotype (growth on toluene, xylenes, toluates) in $100 \%$ of the colonies. All retained the ability to grow on benzoate but no longer produced the yellow colour with catechol or contained any plasmid DNA. No reversion to growth on any of the TOL-specific substrates could be detected.

\section{Cloning of the upper pathway operon}

To identify restriction fragments carrying genes of the upper pathway operon, plasmid pWW0-7000, which carries $x y l U W$ and the 5 -end of $x y l C$ from TOL plasmid pWW0 (Table 1; Williams et al., 1997), was used as a hybridization probe against Southern blots of digests of pWW102. Three fragments reacted positively: an $8.6 \mathrm{~kb}$ HindIII fragment and two EcoRI fragments of 8.2 and $8.7 \mathrm{~kb}$. The appropriate areas were excised from agarose gels, the DNA was extracted and ligated into pUC18, and transformants were checked for hybridization against pWW0-7000 by dot-blotting. Two plasmids with an $8.6 \mathrm{~kb}$ HindIII insert in opposite orientations
(pWW102-7 and pWW102-8) and two with an $8 \cdot 2 \mathrm{~kb}$ EcoRI insert in opposite orientations (pWW102-9 and $\mathrm{pWW} 102-10)$ were identified. When the inserts of pWW102-7 and pWW102-9 were mapped for several restriction sites (Fig. 2), comparison of the maps indicated an overlap of about $5.5 \mathrm{~kb}$ which was confirmed by cross-hybridization (data not shown).

\section{Functional analysis of upper pathway genes}

E. coli containing each of pWW102-7 and pWW102-9 produced pink colonies which turned blue on LB agar plates and produced insoluble blue particles in LB. This reaction is diagnostic for the conversion of tryptophan, present in the medium, to indigo and can be effected by the presence of cloned $x y l M A$, encoding xylene monooxygenase (Mermod et al., 1986; Keil et al., 1987). Two enzymes of the upper pathway operon $x y l U W C M A B N$ were identified by direct assay. Significant activity of benzyl alcohol dehydrogenase (XylB) was demonstrated in the strain containing pWW102-9 and of benzaldehyde dehydrogenase (XylC) in strains carrying either pWW102-7 or pWW102-9 (data not presented).

\section{Location of genes of the upper pathway operon}

Southern hybridization of digests of pWW102-7 and pWW102-9 located $x y l U W, x y l C, x y l A$ and $x y l B$ in the positions shown (Table 2). This location of $x y l B$ appears to conflict with the fact that XylB activity was expressed only from $p W W 102-9$ and not from $p W W 102-7$. It must be that the gene extends beyond the end of pWW102-7 (at coordinate $25 \cdot 2 \mathrm{~kb}$ ) but insufficiently far to hybridize at detectable levels beyond the HindIII site. No probes were used for $x y l M$ or for $x y l N$.

\section{Cloning of the meta pathway operon}

Two plasmids carrying meta pathway genes were identified from a library of plasmid fragments inserted 
Table 2. Summary of Southern blot hybridization of gene-specific probes against digests of plasmids containing fragments from pWW102 DNA

\begin{tabular}{|llllc|}
\hline Probe & $\begin{array}{c}\text { Gene(s) } \\
\text { carried }\end{array}$ & $\begin{array}{c}\text { Source of } \\
\text { probe genes* }\end{array}$ & $\begin{array}{c}x y l \\
\text { homologue }\end{array}$ & $\begin{array}{c}\text { Coordinates } \\
(\mathbf{k b}) \dagger\end{array}$ \\
\hline pWW110-6003 & $b p h X$ & pWW110 & $x y l X$ & $2 \cdot 7-3 \cdot 9$ \\
pVI1300 & $d m p Q$ & pVI150 & $x y l T$ & $5 \cdot 9-7 \cdot 0$ \\
pWW110-4010 & $b p h(T) E$ & pWW110 & $x y l(T) E$ & $5 \cdot 9-8 \cdot 0$ \\
pVI:00 & $d m p B C$ & pVI150 & $x y l E G$ & $6 \cdot 9-9 \cdot 3$ \\
pVI1308 & $d m p D$ & pVI150 & $x y l F$ & $8 \cdot 0-9 \cdot 3$ \\
pVI1309 & $d m p E$ & pVI150 & $x y l J$ & $10 \cdot 2-10 \cdot 9$ \\
pVI1310 & $d m p F$ & pVI150 & $x y l Q$ & $10 \cdot 9-12 \cdot 2$ \\
pVI1312 & $d m p G$ & pVI150 & $x y l K$ & $12 \cdot 1-13 \cdot 1$ \\
pVI1313 & $d m p H$ & pVI150 & $x y l l$ & $12 \cdot 4-13 \cdot 3$ \\
pVI1314 & $d m p J$ & pVI150 & $x y l H$ & $13 \cdot 3-14 \cdot 8$ \\
PCR $x y l H \neq$ & $x y l H$ & pWW102 & $x y l H$ & $13 \cdot 0-15 \cdot 2$ \\
pMT100 & $x y l S$ & pWW0 & $x y l S$ & $15 \cdot 2-16 \cdot 6$ \\
pWW53-3340S & $x y l R$ & pWW53 & $x y l R$ & $19 \cdot 1-20 \cdot 7$ \\
pWW0-7000 & $x y l U W(C)$ & pWW0 & $x y l U(C)$ & $19 \cdot 1-23 \cdot 1$ \\
PCR $x y l C \neq$ & $x y l C$ & pWW0 & $x y l C$ & $23 \cdot 1-25 \cdot 2$ \\
PCR $x y l A \ddagger$ & $x y l A$ & pWW0 & $x y l A$ & $23 \cdot 1-25 \cdot 2$ \\
PCRxylB $\neq$ & $x y l B$ & pWW0 & $x y l B$ & \\
\hline
\end{tabular}

* Sources of probe DNA are the biphenyl catabolic plasmid pWW110 (Carrington et al., 1994), TOL plasmids pWW0 (this study), pWW53 (Keil et al., 1985) and pWW102 (this study), and phenol catabolic plasmid pVI150 (Shingler et al., 1992); all pVI plasmids were prepared and supplied by V. Shingler, Umeå University, Sweden.

†The coordinates are presented as the minimum span of the gene(s) as deduced from the hybridization obtained and the restriction map presented in Fig. 2. Because of the location of available restriction sites, they represent a region potentially larger than the size of the gene itself but within which it is substantially located.

$¥$ Specific gene probes prepared by PCR using primers derived from the published gene sequences.

$\$ 1.8 \mathrm{~kb}$ BglII-HindIII fragment of pWW53-3301 extracted from gel and used directly to probe.

into pUC18 by using the ability of strains carrying a cloned catechol 2,3-dioxygenase to convert catechol to its yellow product, 2-hydroxymuconic semialdehyde. These contained large overlapping inserts, a $17 \mathrm{~kb}$ HindIII fragment (pWW102-3) and an $11.6 \mathrm{~kb}$ BamHI fragment ( $\mathrm{pWW} 102-6$ ) (Table 1). Both plasmids were completely mapped using 14 restriction enzymes (Fig. 2).

\section{Functional analysis of meta pathway genes}

Confirmation of the presence of meta pathway genes on pWW102-3 and pWW102-6 was obtained by assaying three representative enzymes, catechol 2,3-dioxygenase (XylE), 2-hydroxymuconic-semialdehyde hydrolase (XylF) and 2-hydroxymuconic-semialdehyde dehydrogenase (XylG) (data not shown).

\section{Location of the genes of the meta pathway operon}

The locations of $x y$ l genes on the inserts were determined by hybridizations of Southern blots of restriction digests of plasmid pWW102-3 and three plasmids subcloned from $\mathrm{pWW} 102-6$ (pWW102-61, $\mathrm{pWW102-62}$ and pWW102-63, carrying a $4.0 \mathrm{~kb}$ BamHI-SacI, a $3.1 \mathrm{~kb}$
SacI-SmaI and a $3.6 \mathrm{~kb}$ SmaI fragment, respectively) (Table 1). Three sources of meta pathway genes, all from Pseudomonas catabolic plasmids, were used to prepare gene-specific probes: (1) cloned fragments of the meta pathway genes of the phenol catabolic plasmid $\mathrm{pVI} 150$ carrying parts or complete genes from $\operatorname{dmp} B$ (for catechol 2,3-dioxygenase) downstream (Shingler et al., 1992); (2) for the genes for conversion of benzoate to catechol, fragments carrying $b p h$ genes from the biphenyl catabolic plasmid pWW110 (Carrington et al., 1994); (3) a $0.7 \mathrm{~kb}$ PCR-generated fragment of $x y l H$ genes from the archetypal TOL plasmid pWW0. The hybridization results showed that the gene order of the meta pathway of pWW102 is $x y$ lXYZLTEGFQKIJH (Fig. 2), identical to the lower pathway operon on TOL plasmid pWW0 (Harayama \& Rekik, 1990, 1993).

\section{Location of regulator genes $x y / S$ and $x y / R$}

Using probes prepared from $x y l S$ and $x y l R$ from TOL plasmids pWW0 and pWW53 (Table 2), the homologues from pWW102 were located between coordinates 13.0 and $15.2 \mathrm{~kb}$ and between 15.2 and $16.6 \mathrm{~kb}$, respectively (Fig. 2). 


\section{Linkage between two catabolic operons}

Cross-hybridization of Southern blots of pWW102-6, containing a BamHI insert, and $\mathrm{pWW} 102-7$, containing a HindIII insert, showed that they had in common a $1 \mathrm{~kb}$ HindIII-BamHI fragment at their termini (data not shown). The two fragments are therefore adjacent and overlapping and, together with the other overlapping fragments, span a contiguous $28 \mathrm{~kb}$ of pWW102 DNA (Fig. 2).

\section{Nucleotide sequence of the $x y / Q$ gene}

From the hybridization results, $x y l Q$ (for ADA) was shown to be located between the KpnI and SalI sites at coordinates 10.0 and $12.2 \mathrm{~kb}$ (Fig. 2) and on the subclone pWW102-62 (Table 1). Three subclones of this region were made carrying as inserts a $2 \cdot 2 \mathrm{~kb} K p n \mathrm{I}-S m a \mathrm{I}$ fragment (pWW102-622), a $2 \cdot 1 \mathrm{~kb}$ EcoRI-SmaI fragment (pWW102-623) and a $1 \mathrm{~kb}$ SalI-SalI fragment

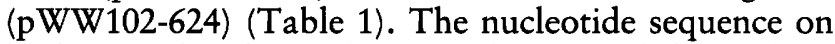
both strands of $1611 \mathrm{bp}$ was determined from these plasmids. The ORF of $x y l Q(921 \mathrm{bp}$ ) encodes a protein with a predicted molecular mass of $33 \mathrm{kDa}$. Upstream of $x y l Q$ is the $3^{\prime}$-end of an ORF of 82 codons, giving 25 amino acids which showed $96.4 \%$ homology with the Cterminus of NahI from pWW60-22 (Platt et al., 1995), and is therefore identified as $x y l J$, the gene for 2oxopent-4-enoate hydratase. Downstream of $x y l Q$ is the 5 -end of an ORF of 140 codons giving a protein sequence of 134 residues which is $75.2 \%$ identical with the $\mathrm{N}$-terminus of $\mathrm{NahM}$, and is thereby identified as $x y l H$, the gene for 4-hydroxy-2-oxovalerate aldolase.

\section{Enzyme assay and electrophoretic analysis of expressed ADA proteins}

The 3.1 kb SacI-Smal insert of pWW102-62 was excised and re-ligated into expression vector $\mathrm{pTrc} 99 \mathrm{a}$ to form plasmid pWW102-62E. After induction with IPTG, both E. coli JM109(pWW102-62) and E. coli JM109(pWW102-62E) expressed high ADA activities [400$500 \mathrm{mU}$ (mg protein $)^{-1}$ ] compared with induced cells of $P$. putida $\mathrm{O}_{2} \mathrm{C}_{2}$, where the activity was about $12 \mathrm{mU}(\mathrm{mg}$ protein $\left.^{-1}\right)$. Extracts were also submitted to SDS-PAGE and showed the presence of a strongly expressed protein with a molecular mass of $35 \mathrm{kDa}$, in fair agreement with that predicted from the deduced amino acid sequence of the corresponding ADA protein (data not presented).

\section{DISCUSSION}

The large plasmid pWW102 of $P$. putida strain $\mathrm{O}_{2} \mathrm{C}_{2}$ appears to confer the phenotypic properties of other TOL plasmids. It too is counterselected by growth on benzoate minimal medium (Williams \& Murray, 1974; Williams \& Worsey, 1976), and the plasmid is totally lost after just one cycle of 20 generations. High frequencies of loss have been noted before but those plasmids which exhibited it appeared to segregate deletion mutants in which some of the TOL-encoded phenotypes were retained (Pickup \& Williams, 1982;
Keil \& Williams, 1985; Osborne et al., 1988; O’Donnell \& Williams, 1991). pWW102 is the first example where the high frequency of loss is associated with complete loss of the plasmid.

The organization of the $x y l$ operons on pWW102 is different from any described before. However, within each of the two catabolic operons and the two adjacent but divergently expressed regulatory genes, we can detect no difference from any of the previously reported plasmids. Given that (a) our analysis of gene location has a degree of imprecision due to the location of restriction sites available, (b) we did not use genespecific probes for all 24 of the genes (probes for $x y l Y, Z, L, N$ were absent) and (c) we did not determine the directions of transcription, there is nothing which would make us doubt that the internal operonic organization differed from that in $\mathrm{pWW} 0$. The organization of the operons is novel and, compared with the archetype $\mathrm{pWW} 0$, the two catabolic operons are reversed in order, $x y l U W C M A B N$ being located downstream of $x y l X Y Z L T E G F J Q K I H$. pWW102 does bear considerable similarity to pWW53 in that all its $x y l$ genes are in the same orientation and proximity as are the pWW53 meta pathway operon 1, the regulatory pair $x y l S R$ and the single upper pathway operon. We have acquired no evidence during this study of pWW102 to suggest that $\mathrm{pWW} 102$ has any of the $x y l$ gene duplications found on pWW53 (Osborne et al., 1988) or on pWW15 (O'Donnell \& Williams, 1991).

Sequencing of $x y l Q$ confirmed that the gene encoding ADA is within the meta pathway operon of $\mathrm{pWW} 102$ in the place indicated by DNA-DNA hybridization. On either side of $x y l Q$ are partial reading frames confirming the gene order is $x y l J Q K$, just as found on the TOL plasmid pWW0 (Harayama \& Rekik, 1990). This group of three genes is found in the same order in a number of pathways which involve extradiol cleavage of the aromatic ring. In the $x y l$ meta pathway operon of TOL plasmids, the $d m p$ operon of phenol catabolic plasmid pVI150 (Shingler $e t$ al., 1992) and the second nab operon of naphthalene catabolic plasmid pWW60-22 (Platt et al., 1995) it is located towards the end of a conserved gene cluster (homologous to $x y l T L E G F J Q K I H)$ encoding the conversion of catechol to central metabolites: in each case, however, the first genes of the operon differ and encode the conversion of a chemically stable compound (benzoate, phenol and salicylate, respectively) to catechol. The same group of homologues of these three genes is also found in the same order (a) as the terminal three genes in the adjacent cumate (cmtFHG) (Eaton, 1996) and toluene (todGIH) (Lau et al., 1994) operons of $P$. putida F1, (b) in several biphenyl $(b p h)$ 'upper' operons, where they are involved in the catabolism of the 2-hydroxypenta-2,4-dienoate formed as the product after cleavage of the first ring of the biphenyl (Kikuchi et al., 1994; Hofer et al., 1994; Kimura et al., 1997; GenBank accession no. D85853) and (c) in the pathway for cumene (isopropylbenzene) catabolism (cumFGH) (Habe et al., 1996). In all these latter examples the three genes are found with adjacent 
(a)

TodI

Xy10_pWWO

XYlQ_pDK1
DmpF

CmtH

Naho

Xy10_pWH 102

BphX2_KF707

\section{TodI}

BphG_KKS102

XY10 PDK

DmpF

Naho

XY10_pwW 102

SphX2_KF707

CumG

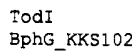

ByhG_KKS10

XY1Q_pWWO

DmpF

CmtH

XYlQ_pww102

BphJ

BphX2_KE707

TodI

BphG_KKS102

XY10_pWW

Xy10_pDK

DmpF

$\mathrm{CmtH}$

Naho

BphX2_KF707

CumG

TodI

BphG_KKSIO2

XY10_pwW

XY10_PDK1

DmpF

$\mathrm{CmtH}$

Xyle_pww 02

BphJ

BphX2_KF707

TodI

BphG_KKSIO2

Xy10_pwW

XY1Q_pDK1

DmpF

CintH

Xy10 pww102

Bph

BphX2_KE707

Cums

TodI

xy10_pDK1

Xylo_pDK
DmpF

CmtH

Xy1Q_pWW1 02

BphJ

BphX2_KE707

CumG
BphG_KKS102

XY1Q_pWWO

11

21

3

41

...MTRKVKA AIIGSGNIGT DLMIKILRHG OHIEMGAMVG IDPASDGLAR ..MTRKLKA AIIGSGNIGT DLMIKIISTA DSVEMGAMVG IDAASDGLAR MNKKLKV AIIGPGNIGT DLMIKVMRNA OYLEMGAMVG IDPASDGLAR MSKKLKV AIIGPGNIGT DLMIKVMRNA EHLEMGAMVG IDPASDGLAR .MNQKLKV AIIGSGNIGT DLMIKVLRNA KYLEMGAMVG IDAASDGLAR MOTHDGKTAV AIIGSGNIGT DLMVKILRHG KHLRMGAFVG IDPESDGLKR ‥MSKKLKA AIIGPGNIGT DLVMKMLR.S ENIEPVWMVG IDPNSDGLKR ...MSKKLKA AIIGPGNIGT DLVMKMLR.S EWIEPVWMVG IDPNSDGLKR MTKKIKC ALIGPGNIGT DLLAKLOR.S PVLEPIWMVG IDPESDGLKR ...MTKKIKC ALIGPGNIGT DLLAKLOR.S PVLEPIWMVG IDPESDGLKR ....MNKIKC ALIGPGNIGT DLLYKLQR.S TVLEPVWMVG VDPTSEGLRR ** *********** ${ }^{*}$ ******* GERMGVAITH EGVEGLTRLP VFNEIDVVFD ATSAGAHVKN EAILRERKPG OALGVATTH EGAEGITRLP VFADIDTVED ATSAGAHVKN DALTRHHKPA AORMGVATTH EGVEGFINLP EFADIDFVED ATSASAHVON DALLRRAKPG AQRMGVATTH EGVEGLINLP EFADIDFVED ATSASAHVRN DALTRPAKPG AORMGVTTTY AGVEGLIKLP EFADIDEVED ATSASAHYON FALIROAKPG AERMGVPTVS TGIEGLLSHP DFGSIGFVFD ATSAGAHARH EALLRPH ARDFGMKTTA EGVDGLLPHV LDDDIRIAFD ATSAYVTAEN SRKLNAL.G AREFGMKTTA EGVDGLLPHV IDDDIRIAFD ATSAYVHATN SRKINAL AREMGIKTTA DGVDGLIPHM DADGVIVD ATSAYVHAEN SRKLNAL...G AREMGIKTTA DGVDGIIPHY OADGVOTVTD ATSAYVHADN SRKVML. G AREMGIKTA DGVDGLIPTM OADGVQIVFD ATSAYVIADN SRKVNAL..

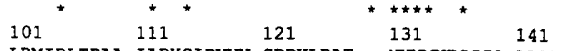
LRMIDLTPAA IAPYCIPVVN GDDHLDAT.. NVNMVTCGGQ ATIPMVAAVS IRI DLIPAA IGPYCIPVNN GEDHIAL.. NVMVIGGO ATIPMVAAVS IRLIDLIPAA IGPYCIPVVN GEDHEAL. WVMVTCGG ATIBMVAVS

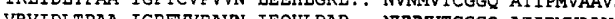

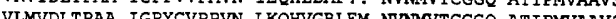
VIMVDTPAA IGPYCVPPW LKN AIMIDIPAA IGPYCVPVN LKQHVGLEM NMWVTCGQ ATIPMVAAVS ALMIDLIPAA IGPCVPIVN LKEHVGKGM NMMVGGQ ATIPMVAAVS

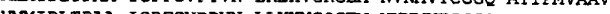
MMIDETPAA IGPFCVPPVN LLKHVGQGEM NWNMVTCGGQ ATIPMVAAVS

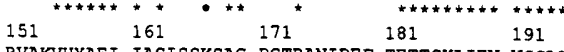

RVAKVHYAE I IASISSKSAG PGTRANIDEF TETTSKAIEV VGGAAKGKAI RVAKVOYGEI VASISSKSAG PGTRANIDEF TETTSKAIEV VGGAAKGKA RVAKVHYAEI VASIASKSAG PGTRANIDEF TETTSKAIEV IGGAAKGKA RVAKVHYAEI VASIASKSAG PGIRANIDEF TETTSKAIEV IGGAAKGKA RVAKVHYAEI VASISSKSAG PGTRANIDEF TETTSKAIEV IGGAAKGKAI RVVPVEYAEI VASISSRSAG PGTRANIDEF TETTSNAIVR VGGAORGKAI RVQPVAYAEI VATVSSRSVG PGTRKNIDEF TRTTAGAIEQ VGGAREGKAI RVQPVAYAEI VATVSSRSVG PGTRKNIDEF TRTTAGAIEQ VGGAREGKAI RVQPVAYGEI VATVSSKSAG PGTRKNIDEF TRTTAGAVEK VGGAKKGKAI RVQPVAYGEI VATVSSKSAG PGTRKNIDEF TRTTAGAVEK VGGAKKGKAI RVQPVTYGEI VATTASKSIG PGTRANIDEF TRTTGSAIEI VGGAKKGKAI

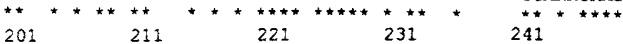
$\begin{array}{lllll}201 & 211 & 221 & 231 & 241 \\ \text { IVLNPAEPPL } & \text { MMRDAVYTLS } & \text {.DFADIDQIE } & \text { ESVQRMADAV } & \text { QAYVPGYRLK }\end{array}$ IVLNPAEPPL MMRDAVYTLS .DFADIDQIE ESVQRMADAV QAYVPGYRLK
IVLNPAEPPL IMRDTVYTLS .DFADTAKIE DSVQRMAAAV QAYVPGYRLK IVMNPAEPPI IMRDTVFVLS .ETVDQAQVE ASVEEMTSAV QAYVPGYRLK I IMNPAEPPL IMRDTVFVLS .EAVDQAQVE ASIEEMASAV QAYVPGYRLK IIMNPAEPPL IMRDTVYVLS .AAADQAAVA ASVAEMVQAV QAYVPGYRLK IILNPAEPPL IMRDTVYCLV PGHADRQAIV ESVERMASAV AAYVPGYRLK IVINPAEPPL MMRDTIHCLT DSEPDOAAIT ASVHAMIAEV OKYVPGYRLK IVINPAEPPL MMRDTIHCLT DSEPDOAAIT VSVHAMIAEV QKYVPGYRLK IILNPAEPPL IMRDTVHCLI ESEPDQAKIT ESIHAMIKEV QKYVPGYKLV IILNPAEPPL IMRDTVHCLL ESEPDQAKIT ESIHAMIKEV OKYVPGYKLV IIINPAEPPM IMRDTVHCLT ETEPDRERIT ASVQKMVKEV OKYVPGYKLV $\begin{array}{lllll}251 & 261 & 271 & 281 & 291 \\ \text { ORVOFDRIFA DCPIRIPGVG DRMNGLKTSI FLEVEGAAHY LPAYAGNLDI }\end{array}$ QRVQFDRIEA DRPIRIPGVG DRLTGLKTSV FLEVEGAAHY LPAYAGNLDI OKVOFDVIPE SAPLHIPGLG .TFSGLKTSI YLEVEGAAHY LPAYASSID OKVQFDMIPA SAPLHIPGLG .TFSGLKTSI YLEVEGAAHY LPAYAGNLDI QQVQFDVIPE SAPLNIPGLG .RFSGLKTSV FLEVEGAAHY LPAYAGNLD QTVQFDEFKG RMPOETGSAO ...APRLKVSV FLEVEGAGHY LPSYAGNLDI NGPVFD. $\ldots \ldots$. NGPVFD $\ldots \ldots \ldots$. NGPVFD $\ldots \ldots \ldots \ldots \ldots, \ldots$, GLRVSV YLEVEGLGDY LPKYAGNLD NGPVFD $, \ldots, \ldots \ldots \ldots \ldots \ldots$ GLRVSV YLEVEGLGDY LPKYAGNLDI NGPVFD $\ldots \ldots \ldots \ldots \ldots \ldots$ GKRISL FLEVEGLGDY LPKYAGNLDI $301 \quad 311 \quad 321 \quad 331$

MTSAALRTAE KLAERLLASL VA

MTSAALRTAE KMAQRLLATL TA

MTSAALATAE RMAQSLLNA

MTSAALATAE RMAQSLLNA

MTSAALATAE RMAQSMLNA

MTSAALATAE RTAARONAA

MTAAALRTGE MEAEEIAAGT IOLPRRDIAL A

MTAAATTGE MFAEETAAGT ILLRRDIAF A

MTAAAARTAE MFAEEIIAGO LTLOPVHA

MTAAAARTAE MFAETLE LTLQPVHA

MTAAAVRTAE MFAEEISSGK LKLGPTIETQ K

*****.

genes either unrelated or only distantly related to those which surround them in the $x y l, n a b$ and $d m p$ operons.

A model for the evolution of the Pseudomonas meta pathway operons which has been proposed involves the recombination of pre-evolved genetic modules to give (b)

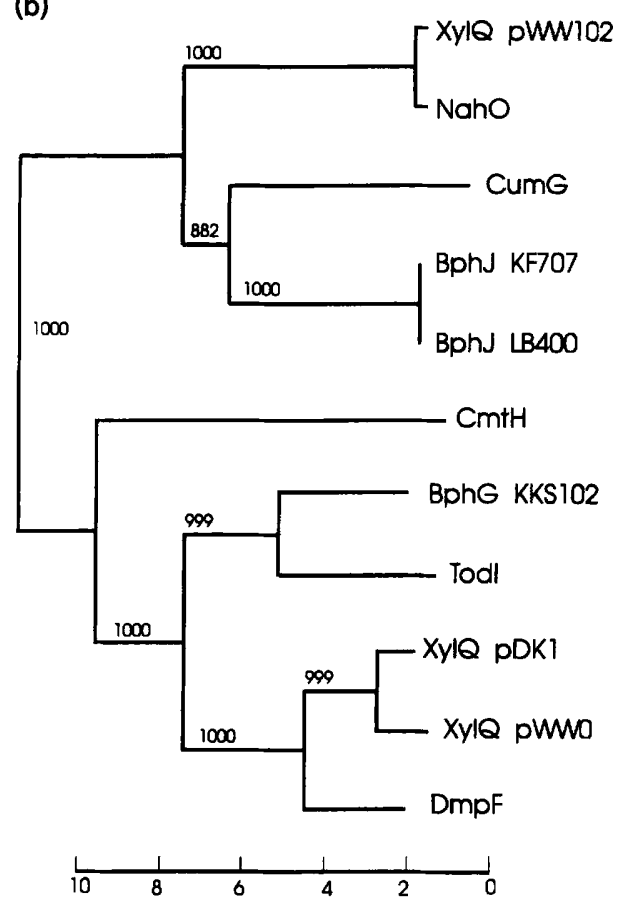

Fig. 3. Comparisons of amino acid sequences of ADA proteins from Pseudomonas catabolic pathways. The sequences were obtained from GenBank with accession numbers: XylQ (plasmid pWW102), this work; NahO, U13232; CumG, D63377; BphJ (strain KF707), D85853; BphJ (strain LB400), X76500; CmtH, U24215; BphG (strain KKS102), D16407; Todl, U09250; XyIQ (plasmid pDK1), R. J. Benjamin, personal communication; XylQ (plasmid pWW0), M94186; DmpF, X60835. (a) Alignments produced by CLUSTAL W 1.7 (Thompson et al., 1994), using the BLOSUM series of amino acid weight matrices with gap penalty 10 and gap extension penalty $0 \cdot 1$. Residues conserved in all sequences are marked with an asterisk. (b) Dendrogram drawn from the CLUSTAL alignment using the built in neighbourjoining function (Saitou \& Nei, 1987). The numerical values are the bootstrap values with 1000 trials. The scale represents percentage divergence.

the gene arrangements seen in modern strains (Cane $\&$ Williams, 1986; Harayama et al., 1987; Assinder \& Williams, 1988; van der Meer et al., 1992; Williams \& Sayers, 1994). In the case of the $x y l$ meta pathway operon, we can see evidence for three such 'modules'. The first and largest is the homologous sequence 
equivalent to $x y l T-x y l H$ found in the meta pathway operons for catabolism of toluene/xylene (Harayama \& Rekik, 1993; Keil et al., 1985), phenols (Shingler et al., 1992), salicylate (and therefore naphthalene) (Assinder \& Williams, 1988) and biphenyl (Carrington et al., 1994). The second is located within these operons as the 'submodule' equivalent of $x y l J Q K$ found also in other catabolic operons (see above). The third is upstream within the same operon, the $x y l X Y Z L$ genes for conversion of benzoate to catechol, homologues of which turn up as ben $A B C D$ in the chromosomal $\beta$ ketoadipate pathway in both Acinetobacter calcoaceticus and P. putida (Neidle et al., 1991, 1992).

If all $x y l$ meta pathway operons, for example, share a common ancestor which arose by a modular assembly, then it would be expected that the genes and proteins found in all modern $x y l$ pathways would be more closely related to each other than to those in any other pathway, such as a nab pathway, which would have arisen by an independent assembly and subsequently divergently radiated. However, alignment of the amino acid sequences of Pseudomonas ADA proteins (Fig. 3) shows this expectation not to be the case. Thus XylQ of pWW102 is more closely related to NahO of pWW60-22 than to the other XylQ proteins of TOL plasmids pWW0 and pDK1. Other comparisons of genes within the Pseudomonas meta pathway operons have shown a similar result.

In a detailed comparison of the nucleotide sequences of the meta pathways of pWW0, pVI150 and NAH7, Harayama \& Rekik (1993) showed that the 5'-end of the 'catechol module' on pWW0 was more homologous to the isofunctional nah genes of NAH7, whereas its 3 '-end was closer to the $d m p$ genes of pVI150. They proposed that the $x y l$ operon was the result of recombination between ancestral nab and $d m p$ operons. Analysis of the nucleotide sequence of the $x y l E$ gene on TOL plasmid pDK1 showed that it had an apparent discontinuity in its homology and that its $5^{\prime}$-end was more homologous to $n a b H$ from NAH7 whereas the 3 '-end was closer to $x y l E$ of TOL plasmid pWW0 (Benjamin et al., 1991). Similarly the $x y l S$ regulatory gene on TOL plasmid pDK1 is also clearly a chimera of two different $x y l S$ homologues, one of each of which is found on another TOL plasmid, pWW53 (Assinder et al., 1993). These results suggest that recombination between two sequences, not necessarily encoding the catabolism of the same original substrate, may give rise to hybrid or mosaic patterns within individual genes or within operons. Such an event has been recorded between the duplicate meta pathway operons of TOL plasmid pWW53 (Osborne et al., 1988).

The ADA proteins fall into two clearly differentiated clusters (Fig. 3). This is very apparent in some areas where there are strong identities within the two subclusters but not between them. These are (a) residues 257-274, where all the proteins in the cluster containing XylQ from pWW102 contain the same deletion of 18 residues, and (b) three locations where the two clusters differ by identical small deletions : at positions $29,98-99$ and $129-130$ in the alignment of Fig. 3(a). Exactly the same pattern of clustering is found when the protein sequences of the upstream genes (XylJ homologues) and of the downstream genes (XylK homologues) are compared (data not shown), which shows that in all these strains the $x y l J Q K$ homologues have the same pattern of ancestry. However, there are no clear lineages within any of this cluster of three genes which directly correlate with their metabolic function (Fig. 3b). Thus the pWW102 ADA is closest to the homologous sequence on the naphthalene plasmid pWW60-22 but is in the opposite subcluster to the two TOL plasmid proteins from $\mathrm{pWW} 0$ and $\mathrm{pDK} 1$. In a parallel manner, two of the $b p h \mathrm{ADA}$ proteins are close to the $\mathrm{pWW} 0 \mathrm{XylQ}$, whereas another $b p h$ protein and TodI, the genes for which are very similar in arrangement to $b p h$ genes, are in the other subcluster and closely related to the pWW102 protein. There are two possible explanations : either the gene organizations we see conserved in these pathways have evolved separately on more than one occasion or, more likely in our opinion, recombination between homologous genes in these operons has resulted in mixing of the sequences between different metabolic pathways in a manner equivalent to gene conversion, thus obscuring their origin.

\section{ACKNOWLEDGEMENTS}

We should like to thank Wouter Duetz for strain $\mathrm{O}_{2} \mathrm{C}_{2}$, Vicky Shingler for sending all the plasmids derived from $\mathrm{pVI} 150$ and Linda Shaw for her continued help and advice during the course of this work and in the writing of this paper.

\section{REFERENCES}

Altschul, S. F., Gish, W., Miller, W., Myers, E. W. \& Lipman, D. J. (1990). Basic local alignment search tool. J Mol Biol 215, 403-410.

Assinder, S. J. \& Williams, P. A. (1988). Comparison of the meta pathway operons on NAH plasmid pWW60-22 and TOL plasmid pWW53-4 and its evolutionary significance. J Gen Microbiol 134, 2769-2778.

Assinder, S. J. \& Williams, P. A. (1990). The TOL plasmids: determinants of the catabolism of toluene and the xylenes. Adv Microb Pbysiol 31, 1-69.

Assinder, S. J., De Marco, P., Osborne, D. J., Poh, C. L., Shaw, L. E., Winson, M. K. \& Williams, P. A. (1993). A comparison of the multiple alleles of $x y l S$ carried by TOL plasmids pWW53 and pDK 1 and its implications for their evolutionary relationship. $J$ Gen Microbiol 139, 557-568.

Bartilson, M. \& Shingler, V. (1989). Nucleotide sequence and expression of the catechol 2,3-dioxygenase-encoding gene of phenol-catabolizing Pseudomonas CF600. Gene 85, 233-238.

Benjamin, R. C., Voss, J. A. \& Kunz, D. A. (1991). Nucleotide sequence of $x y l E$ from the TOL pDK1 plasmid and structural comparison with isofunctional catechol 2,3-dioxygenase genes from TOL pWW0 and NAH7. J Bacteriol 173, 2724-2728.

Cane, P. A. \& Williams, P. A. (1982). The plasmid-encoded metabolism of naphthalene and 2-methylnaphthalene in Pseudomonas: phenotypic changes correlated with structural modification of the plasmid pWW60-1. J Gen Microbiol 128, 2281-2290.

Cane, P. A. \& Williams, P. A. (1986). A restriction map of naphthalene catabolic plasmid pWW60-1 and the location of some of its catabolic genes. J Gen Microbiol 132, 2919-2929. 
Carrington, B., Lowe, A., Shaw, L. E. \& Williams, P. A. (1994). The lower pathway operon for benzoate catabolism in biphenylutilizing Pseudomonas sp. strain IC and the nucleotide sequence of the $b p h E$ gene for catechol 2,3-dioxygenase. Microbiology 140 , 499-508.

Chatfield, L. K. \& Williams, P. A. (1986). Naturally-occuring TOL plasmids isolated from soil carry either two homologous or two nonhomologous catechol 2,3-oxygenase genes. J Bacteriol 168, 878-885.

Duggleby, C. J. \& Williams, P. A. (1986). Purification and some properties of the 2-hydroxy-6-oxohepta-2,4-dienoate hydrolase (2-hydroxymuconic semialdehyde hydrolase) encoded by the TOL plasmid pWW0 from Pseudomonas putida mt-2. J Gen Microbiol 132, 717-726.

Eaton, R. W. (1996). p-Cumate catabolic pathway in Pseudomonas putida $\mathrm{F} 1$. Cloning and characterization of DNA carrying the CMT operon. J Bacteriol 178, 1351-1362.

Girvitz, S. C., Bacchetti, S., Rainbow, A. J. \& Graham, F. W. (1980). $A$ rapid and efficient procedure for the purification of DNA from agarose gels. Anal Biochem 106, 492-496.

Guerry, P., Leblanc, D. J. \& Falkow, S. (1973). General method for isolation of plasmid deoxyribonucleic acid. J Bacteriol 116, 1064-1066.

Habe, H., Kimura, T., Nojiri, H., Yamana, H. \& Omori, T. (1996). Cloning and nucleotide sequences of the genes involved in the meta cleavage pathway of cumene degradation in Pseudomonas fluorescens IP01. J Ferment Bioeng 81, 187-196.

Harayama, S. \& Rekik, M. (1990). The meta-cleavage operon of TOL degradative plasmid pWW0 comprises 13 genes. Mol Gen Genet 222, 113-120.

Harayama, S. \& Rekik, M. (1993). Comparison of the nucleotide sequences of the meta-cleavage pathway of TOL plasmid $\mathrm{pWW0}$ from Pseudomonas putida with other meta-cleavage genes suggests that both single and multiple nucleotide substitutions contribute to enzyme evolution. Mol Gen Genet 239, 81-89.

Harayama, S., Rekik, M., Wasserfallen, A. \& Bairoch, A. (1987). Evolutionary relationship between catabolic pathways for aromatics: conservation of gene order and nucleotide sequences for catechol oxidation genes of $\mathrm{pWW} 0$ and NAH7 plasmids. Mol Gen Genet 210, 241-247.

Harayama, S., Rekik, M., Wubbolts, M., Rose, K., Leppik, R. A. \& Timmis, K. N. (1989). Characterization of 5 genes in the upper pathway operon of TOL plasmid pWW0 from Pseudomonas putida and identification of the gene products. J Bacteriol 171, 5048-5055.

Hofer, B., Backhaus, S. \& Timmis, K. N. (1994). The biphenyl/ polychlorinated biphenyl-degradation locus $(b p h)$ of Pseudomonas sp. LB400 encodes four additional metabolic enzymes. Gene 144, 9-16.

Holmes, D. S. \& Quigley, M. (1981). A rapid boiling method for the preparation of bacterial plasmids. Anal Biochem 114, 193-197.

Keil, H. \& Williams, P. A. (1985). A new class of TOL plasmid deletion mutants in Pseudomonas putida MT15 and their reversion by tandem gene amplification. J Gen Microbiol 131, 1023-1033.

Keil, H., Keil, S., Pickup, R. W. \& Williams, P. A. (1985). Evolutionary conservation of genes coding for meta pathway enzymes within TOL plasmids pWW0 and pWW53. J Bacteriol 164, 887-895.

Keil, H., Saint, C. M. \& Williams, P. A. (1987). Gene organization of the first catabolic operon of TOL plasmid pWW53: production of indigo by the $x y l A$ gene product. $J$ Bacteriol $169,764-770$.
Kikuchi, Y., Yasukochi, Y., Nagata, Y., Fukuda, M. \& Takagi, M. (1994). Nucleotide sequence and functional analysis of the metacleavage pathway involved in biphenyl and polychlorinated biphenyl degradation in Pseudomonas sp. strain KKS102. J Bacteriol 176, 4269-4276.

Kimura, N., Nishi, A., Goto, M. \& Furukawa, K. (1997). Functional analyses of a variety of chimeric dioxygenases constructed from two biphenyl dioxygenases that are structurally similar but different functionally. J Bacteriol 179, 3936-3943.

King, E. D., Ward, M. K. \& Raney, D. C. (1954). Simple method for the demonstration of pyocyanin and fluorescein. $J$ Lab Clin Methods 44, 301-307.

Lau, P. C. K., Bergeron, H., Labbé, D., Wang, Y., Brousseau, R. \& Gibson, D. T. (1994). Sequence and expression of the todGIH genes involved in the last three steps of toluene degradation by Pseudomonas putida F1. Gene 146, 7-13.

van der Meer, J. R., De Vos, W. M., Harayama, S. \& Zehnder, A. B. (1992). Molecular mechanisms of genetic adaptation to xenobiotic compounds. Microbiol Rev 56, 677-694.

Mermod, N., Harayama, S. \& Timmis, K. N. (1986). New route for the bacterial production of indigo. Biotechnology 4, 321-324.

Neidle, E. L., Hartnett, C., Ornston, L. N., Bairoch, A., Rekik, M. \& Harayama, S. (1991). Nucleotide sequences of the Acinetobacter calcoaceticus ben $A B C$ genes for benzoate dioxygenase reveal evolutionary relationships among multicomponent oxygenases. $J$ Bacteriol 173, 5385-5395.

Neidle, E. L., Hartnett, C., Ornston, L. N., Bairoch, A., Rekik, M. \& Harayama, S. (1992). Cis-diol dehydrogenases encoded by the TOL ( $\mathrm{WWWO}$ ) plasmid and the Acinetobacter calcoaceticus chromosomal benD gene are members of the short-chain alcohol dehydrogenase superfamily. Eur J Biochem 204, 113-120.

O’Donnell, K. \& Williams, P. A. (1991). Duplication of both $x y l$ operons on TOL plasmid pWW15. J Gen Microbiol 137, 2831-2838.

Osborne, D. J., Pickup, R. W. \& Williams, P. A. (1988). The presence of two complete homologous meta pathway operons on TOL plasmid pWW53. J Bacteriol 134, 2965-2975.

Pickup, R. W. \& Williams, P. A. (1982). Spontaneous deletions in the TOL plasmid pWW20 which give rise to the B3 mutants of Pseudomonas putida MT20. J Gen Microbiol 128, 1385-1390.

Platt, A., Shingler, V., Taylor, S. C. \& Williams, P. A. (1995). The 4hydroxy-2-oxovalerate aldolase and acetaldehyde dehydrogenase (acylating) encoded by the nahM and nabO genes of the naphthalene catabolic plasmid pWW60-22 provide further evidence of conservation of meta-cleavage pathway gene sequences. Microbiology 141, 2223-2233.

Polissi, A. \& Harayama, S. (1993). In vivo reactivation of catechol 2,3-dioxygenase mediated by a chloroplast-type ferredoxin - a bacterial strategy to expand the substrate specificity of aromatic degradative pathways. EMBO $J 12,3339-3347$.

Saitou, N. \& Nei, M. (1987). The neighbour-joining method - a new method for reconstructing phylogenetic trees. Mol Biol Evol 4, 426-444.

Sala-Trepat, J. M. \& Evans, W. C. (1971). The meta cleavage of catechols by Azotobacter species. Eur J Biochem 20, 400-413.

Sambrook, J., Fritsch, E. F. \& Maniatis, T. (1989). Molecular Cloning: a Laboratory Manual, 2nd edn. Cold Spring Harbor, NY: Cold Spring Harbor Laboratory.

Shingler, V., Powlowski, J. \& Marklund, U. (1992). Nucleotide sequence and functional analysis of the complete phenol/3,4 dimethylphenol catabolic pathway of Pseudomonas sp. strain CF600. J Bacteriol 174, 711-724. 
Southern, E. M. (1975). Detection of specific sequences among DNA fragments separated by gel electrophoresis. J Mol Microbiol 98, 503-517.

Thompson, J. D., Higgins, D. G. \& Gibson, T. J. (1994). CLUSTAL W-improving the sensitivity of progressive multiple sequence alignment through sequence weighting, position-specific gap penalties and weight matrix choice. Nucleic Acids Res 22, 4673-4680.

Vieira, J. \& Messing, J. (1982). The pUC plasmids, an M13mp7derived system for insertion mutagenesis and sequencing with synthetic universal primers. Gene 19, 259-268.

Wheatcroft, R. \& Williams, P. A. (1981). Rapid methods for the study of both stable and unstable plasmids in Pseudomonas. $J$ Gen Microbiol 124, 433-437.

Williams, P. A. \& Murray, K. (1974). Metabolism of benzoate and the methylbenzoates by Pseudomonas putida (arvilla) mt-2: evidence for the existence of a TOL plasmid. $J$ Bacteriol 120, 416-423.

Williams, P. A. \& Sayers, J. R. (1994). The evolution of pathways for aromatic hydrocarbon oxidation in Pseudomonas. Biodegradation 5, 195-217.
Williams, P. A. \& Worsey, M. J. (1976). Ubiquity of plasmids in coding for toluene and xylene metabolism in soil bacteria: evidence for the existence of new TOL plasmids. J Bacteriol 125, 818-828.

Williams, P. A., Shaw, L. E., Pitt, C. W. \& Vrecl, M. (1997). $x y l U W$, two genes at the start of the upper pathway operon of TOL plasmid pWW0, appear to play no essential part in determining its catabolic phenotype. Microbiology 143, 101-107.

Worsey, M. J. \& Williams, P. A. (1975). Metabolism of toluene and xylenes by Pseudomonas putida (arvilla) $\mathrm{mt}-2$ : evidence for a new function of the toluene plasmid. $J$ Bacteriol 124, 7-13.

Worsey, M. J., Franklin, F. C. H. \& Williams, P. A. (1978). Regulation of the degradative pathway enzymes coded for by the TOL plasmid ( $\mathrm{pWW}$ ) from Pseudomonas putida mt-2. J Bacteriol 134, 757-764.

Yanisch-Perron, C., Vieira, J. \& Messing, J. (1985). Improved M13 phage cloning vectors and host strains: nucleotide sequences of the M13mp18 and pUC19 vectors. Gene 33, 103-119.

Received 14 November 1997; revised 26 January 1998; accepted 10 February 1998. 